\title{
Vitamino D koncentracijos pokyčių itaka astmos išsivystymui ir eigai
}

Laura Žilinskaitė, Brigita Šitkauskienė

LSMU MA Pulmonologijos ir imunologijos klinika

Reikšminiai žodžiai: vitaminas D, astma.

Santrauka. Astma yra visame pasaulyje paplitusi lètinė kvejpavimo takų uždegimo liga, kurios patogenezė iki galo neištirta. Mokslininkai kelia hipotezę, kad viena iš astmos patogenezės grandžių galètų būti susijusi su vitamino D stoka. Šio straipsnio tikslas apžvelgti mokslinių tyrimų, vertinančių vitamino D reikšmę astmos patogenezėje, duomenis. Daugumos tyrimų rezultatai rodo, kad astma sergančių asmenų kraujyje nustatoma reikšmingai mažesnė vitamino $D$ koncentracija nei sveikų asmenų bei randamas ryšys tarp vitamino D kiekio ir eozinofilų, bendrojo imunoglobulino E ir plaučių funkcijos rodiklių.

\section{IVADAS}

Astma - lètinẻ kvẻpavimo taku uždegimo liga, labai paplitusi visame pasaulyje [1]. Remiantis Pasaulio sveikatos organizacijos (PSO) $2011 \mathrm{~m}$. duomenimis, pasaulyje ja serga $235 \mathrm{mln}$. žmonių [2]. Astma - dažniausia lètinè vaiku liga. Nors jos patogenezès mechanizmai aktyviai tiriami ir nemažai ju jau nustatyta, vis dèlto ligos patogenezė vis dar nevisiškai aiški. Pagal vieną iš mokslininkų teorijų, astmos išsivystymas gali būti susijęs su vitamino D stoka. Šis vitaminas geriausiai žinomas kaip kalcio ir fosforo apykaitoje dalyvaujanti ir kaulu mineralizacija skatinanti medžiaga [3]. Moksliniai tyrimai rodo, kad vitamino D vaidmuo yra kur kas svarbesnis ir platesnis [4, 5]. Jis gali dalyvauti onkologiniu, endokrininių, kardiovaskulinių, psichikos, autoimuninių, alerginiu ir respiracinių ligu, įskaitant astmą, patogenezèje $[6,7,8]$. Šio straipsnio tikslas - apžvelgti mokslinius vitamino D įtakos astmos patogenezei tyrimus.

\section{VITAMINAS D IR JO APYKAITA}

Vitaminas D priklauso riebaluose tirpių vitaminu grupei. Kalcitriolis yra veikli vitamino D forma (1,25-(OH)2D3). Jo sintezè vyksta trimis etapais [9]. Pirmiausiai ultravioletinè saulès spinduliuotè odos epidermio keratinocituose 7-dehidrocholesterolį verčia ị previtaminą D3, kuris virsta vitaminu D3 (cholekalciferoliu). Vitaminą D iš odos i kraują perneša savitasis baltymas. Vitaminas D3 i organizmą patenka ir su maistu: valgant žuvị, pieną ir jo produktus. Vèliau kepenyse vitaminas D3 hidroksilinamas i 25-OH-D3, po to inkstų artimųjų vamzdelių mitochon- drijose 25-OH-D3 antrą kartą hidroksilinamas, ir susidaro hormonas kalcitriolis. Pagrindiniai hormonai, kurie reguliuoja vitamino D apykaitą, yra kalcitoninas ir parathormonas (PTH). Kalcitoninas slopina 1,25-(OH)2D3 sintezę inkstuose, o parathormonas skatina. Suvokti vitamino D apykaitą svarbu tiriant jo koncentraciją kraujo serume. Norint ištirti tikrąją vitamino D koncentraciją, reikia matuoti 25-OH-D3 kiekị kraujo serume. Šia forma yra kaupiamos vitamino $\mathrm{D}$ atsargos organizme. Tiriant veikliosios vitamino D formos kieki (1,25-(OH)2D3), reikètų atkreipti dèmesi $i$ tai, kad ši forma jau yra du kartus metabolizuota kepenyse ir inkstuose, jos apykaita labai priklauso nuo hormonu, kuriuos gamina skydliaukè ir prieskydinès liaukos, todèl, esant šiu organų funkcijos sutrikimui, galimi klaidingi vitamino D koncentracijos tyrimo rezultatai.

Vitamino D koncentraciją rekomenduojama tirti rudenị ir žiemą, nes vasarą visada nustatoma didesnè ir neatspindi tikrojo sukaupto vitamino D kiekio organizme. Rekomenduojama vitamino D kiekio (25-OH-D3) norma kraujo serume yra 30-150 ng/ml [43]. Tokias plačias normos ribas lèmè skirtingas saulètų dienų skaičius įvairiuose regionuose. Šalyse, kuriose šiltasis metu laikas trunka trumpiau, vitamino D koncentracija yra mažesnè lyginant su karšto klimato šalimis. Naujausiose publikacijose nurodoma, kad 25-OH-D3 koncentracija kraujo serume turi viršyti $20 \mathrm{ng} / \mathrm{ml}$, nes tada gerokai sumažèja vėžio, infekcijų, širdies ir kraujagyslių, metabolinių ligų, kaulu lūžių rizika [10]. Vis dèlto rekomenduojama vitamino D koncentraciją palaikyti didesnę nei $30 \mathrm{ng} / \mathrm{ml}$. Tam reiketų kasdien suvartoti 1500-2000 TV vitamino D [10]. Ženklia vitamino D stoka laikoma $0-10 \mathrm{ng} / \mathrm{ml}$, saikiu stygiumi 10-30 ng/ml, o >150 ng/ml - toksišku kiekiu [3]. 


\section{VITAMINAS D ASTMOS PATOGENEZĖJE}

Mokslo literatūroje pateikiama prieštaringų duomenų apie vitamino D vaidmeni astmos patogenezèje. Vieni autoriai nurodo, kad astma sergančiu vaikų ir suaugusiujjų kraujyje vitamino $\mathrm{D}$ kiekis būna reikšmingai mažesnis nei kontrolinės sveikuju grupès $[6,7,8]$. Kiti mokslininkai nenustato statistiškai reikšmingo vitamino D kiekio skirtumo tarp grupiu [11, 12]. Kai kurie tyrimai rodo, kad nepakankamas vitamino $D$ kiekis susijęs tik su sunkiu astmos paūmèjimu [13].

Vitamino $D$ vaidmuo astmos patogenezèje aiškinamas poveikiu T ląstelèms (pav.). Tyrimuose pastebèta, kad T limfocitu pagalbininkụ (Th) 1 ir Th2 santykis bei padidèjęs uždegimo mediatoriu kiekis reikšmingai susijęs su vitamino D kiekiu [14]. Th2 ląstelès aktyvina interleukiną (IL) 5 ir granuliocituc bei makrofagu kolonijas stimuliuojanti faktoriu (GM-SCF). Šios medžiagos skatina angiogenezę, eozinofilų diferenciaciją ir chemotaksį. Th2 ląstelès aktyvina ir IL-13 gamybą, kas sužadina uždegimą ir persitvarkymo procesus kvėpavimo takuose $[15,16]$. Vitaminas D skatina didèti IL-10 kiekí, o jis yra uždegimą slopinantis citokinas [17]. Sumažèjus šio interleukino kiekiui, pakinta santykis tarp uždegimą skatinančių ir slopinančiu citokinų, o tai skatina uždegimo vystymąsi kvẻpavimo takuose.

Mokslininkai aiškina, kad veiklioji vitamino D forma (1,25-(OH)2D3) gali slopinti uždegimą plaučiu audinyje [18]. Žinoma, kad vitamino D receptoriai yra išsidèstę kvèpavimo takų bei bronchụ lygiưjų raumenų ląstelèse [19]. Plaučiuose esantys vitamino D receptoriai gali patys versti 25-OH-D3 i veikliąją vitamino $\mathrm{D}$ formą 1,25-(OH)2D3 [20, 21]. Vitamino D receptoriu ir hidroksilazès, kuri metabolizuoja veikliąją vitamino D formą, sintezė kvėpavimo takų lygiuụu raumenu ląstelèse yra padidejjusi, todèl vitamino $\mathrm{D}$ gamyba, panaudojimas ir ardymas vyksta labai greitai. Astmos patogenezèje dalyvauja daug genư, susijusiu su vitaminu D: vieni susiję su astma ir alergija, kiti - tik su astma [22].

Manoma, kad yra ryšys tarp vitamino $\mathrm{D}$ ir alerginiu ligų, ypač vaikų $[8,23,24]$. Tai galima paaiškinti vitamino $D$ poveikiu $\mathrm{T}$ ląstelèms ir jų išskiriamiems mediatoriams. Kai kurių tyrimų duomenimis, tarp vitamino $\mathrm{D}$ koncentracijos ir eozinofilu bei bendrojo imunoglobulino (Ig) E kiekio yra neigiamas ryšys [25, 26, 27]. Tai irgi rodytŭ, kad vitamino D stoka susijusi su alergija ir skatina alerginès astmos vystymąsi. Tačiau kiti mokslininkai teigia, kad mažesnis vitamino D kiekis randamas nealerginès astmos atveju, palyginti su alergine astma, ir nèra ryšio tarp vitamino $\mathrm{D}$ kiekio ir eozinofilu bei bendrojo IgE $[11,6,7,13]$.

Kai kurie autoriai nurodo, kad vitamino D kiekis susijęs su $\mathrm{FEV}_{1}$ ir $\mathrm{FEV}_{1} / \mathrm{FVC}[6,7]$. Remiantis šiais duomenimis, galima daryti prielaidą, kad pakankamas kiekis vitamino D galbūt pagerintų plaučiu funkcijos rodiklius sergant astma. Moksliniai tyrimai, atlikti su sveikais asmenimis, rodo, kad vitaminas D apsaugo nuo tabako dūmu sukeliamo poveikio kvépavimo takams [28]. Galima daryti prielaida, kad pakankama vitamino D koncentracija galètu sulètinti tiek sveikų, tiek astma ar kitomis plaučuu ligomis sergančiu rūkančiu asmenų kvejpavimo takuose vykstančius pokyčius, sukeltus rūkalų.

Tyrimų su laboratoriniais gyvūnais duomenimis, vitaminas D sumažina uždegimo procesus [29]. Kai kurie mokslininkai pastebejjo, kad skyrus pacientams vartoti vitamino $D$ preparatu sumažèja gliukokortikoidams atsparios ir vaikams neseniai

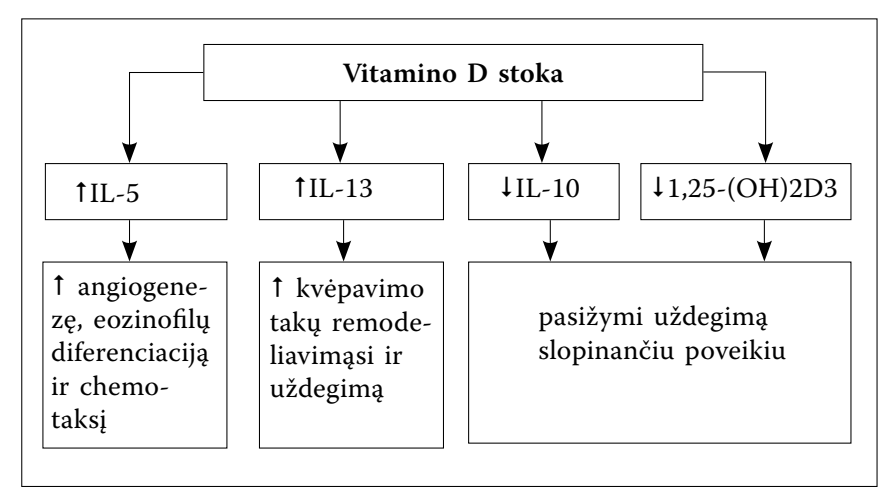

Pav. Vitamino D vaidmuo astmos patogenezeje

diagnozuotos astmos klinikiniai simptomai [30]. Vis dèlto nèra atlikta pakankamai tyrimų su gyvūnais ir astma sergančiais pacientais, kuriuose būtų stebima vitamino D vartojančiu pacientu ligos eiga, todèl pateikti rekomendacijų skirti vitamino D papildu astmos gydymo rezultatams pagerinti, kol kas negalima.

\section{APIBENDRINIMAS}

Remiantis mokslo literatūra, vitamino D stoka gali skatinti astmos išsivystymą, sulètinti ligos eigą. Moksliniai tyrimai rodo, kad mažesnè vitamino D koncentracija nustatoma astma sergančių ligonių kraujo serume ir reikšmingai skiriasi nuo sveikų asmenų tyrimo rezultatų. Vitamino D vaidmuo aiškinamas poveikiu $\mathrm{T}$ ląstelèms ir jų išskiriamiems mediatoriams. Žinoma, kad kvépavimo takų ir bronchų lygiụjų raumenų ląstelèse yra vitamino D receptoriụ, kuriuose šis vitaminas verčiamas ị veikliạją formą, pasižyminčia uždegimą slopinančiu poveikiu. Atrasta daug genų, susijusių su vitaminu $D$, kurie taip pat dalyvauja astmos vystymosi procese. Kai kurie mokslininkai nustate ryši tarp vitamino $D$ kiekio ir eozinofilų, bendrojo imunoglobulino $\mathrm{E}$ ir plaučiu funkcijos rodikliụ. Taigi rekomenduojama kraujyje palaikyti pakankamą kiekị vitamino D - toks jis būna, kai 25-OH-D3 koncentracija kraujo serume yra didesnè nei $30 \mathrm{ng} / \mathrm{ml}$.

\section{IMPACT OF VITAMIN D LEVEL ON DEVELOPMENT AND PROGRESS OF ASTHMA}

\section{LAURA ŽLLINSKAITĖ, BRIGITA ŠITKAUSKIENË LUHS MA DEPARTMENT OF PULMONOLOGY AND IMMUNOLOGY}

Keywords: vitamin D, asthma.

Summary. Asthma is a chronic inflammatory airway disease. Prevalence of this disease is high worldwide. However its pathogenesis is not fully understood. Scientists hypothesize that one of the way of asthma pathogenesis could be related to the lack of vitamin D. The aim of this article is to review research about vitamin D impact on asthma pathogenesis. Studies show that significantly lower vitamin D level is found in blood serum of patients with asthma compared to healthy people. Some scientists note that there is a relation between vitamin D level and eosinophil count, total immunoglobulin $E$ and values of lung function. 